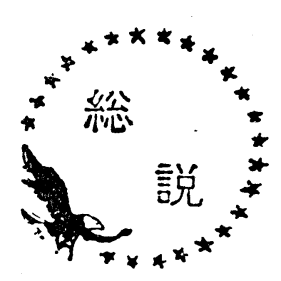

重 油 の直 接 脱硫

一流 動 床 方 式一

——昭和 45 年 3 月 12 日受理一

東京工業試験所 小 寺 嘉 秀

\section{1. ま えがき}

私達は標題の問題を工業技術院の大型プロジェクト の一環として 3 年にわたつて実施してきたが, 最近そ の範囲での目的をほぼ達成したといえそうである。大 型プロジェクトの性格からその公開は今後の問題であ るが，現在まで工業技術院の内部で発表した範囲で本 稿をまとめてみたい。なお筆者は重油の性状などにつ いては全くの門外漢であり，以下の記載に当つても不 備の点が少くないと思われるが，この点はあらかじめ 読者の御了承をえておきたい。

低イオウ重油の製造については一般的な総説1) が多 いが, これらとの重複を知りつつも, 流動床方式の位 置をみるために簡単に概観しよう。燃料用重油は発熱 量当たりの価格がわが国でもつとも安い燃料であり, その使用量の増加とともにその燃焼排気が公害源とし て問題となつてきている。この公害防止の対策として 同じ大型プロジェクトに取上げられた排煙脱硫がある が，効率の点から大型化せざるをえず，大量の重油を 燃焼する火力発電所などでは有利であろらが，一般の 重油燃焼に当たつては応用が限定されることが予想さ れる。このためには低イオウの重油の製造が要求さ れ，この方法として水素化脱硫が現在もつとも有効と 思われる。このばあいにいわゆる固定床方式と流動床 方式があるが，それぞれ長短があり，両者の研究が併 行して行なわれている。なお間接脱硫法については最 近国内でプラントが建設されており，別に御紹介もあ ることと思われるので，ここには触れない。

\section{2. 重油中の各種の化合物}

原油中にもともと含まれている炭化水素以外の化合 物を元素別にみて量の比較的多いものを記すと, イオ ウ，バナジウムまたはニッケルなどである。この詳細 は別に記されているので, 表 1 および 2 について以下 の記述を説明しておこう。

表 1 は原油によるイオウの量の差を示し, 蒸留の方 法で残油をどの程度残すかによつて変わるので, 残油 中のイオウの量のつぎに, 残油の原油に対する収率を 容量パーセントで示した。このイオウの化合物の種類 は大部分がチオフェン類であるといわれている。

表 2 は常圧残油中のイオウおよび金属の含有量を原 油別に示している。金属元素は油溶性化合物として含

表 1 原油別イオウ分

(カッコ内残油收率 Vol\%)

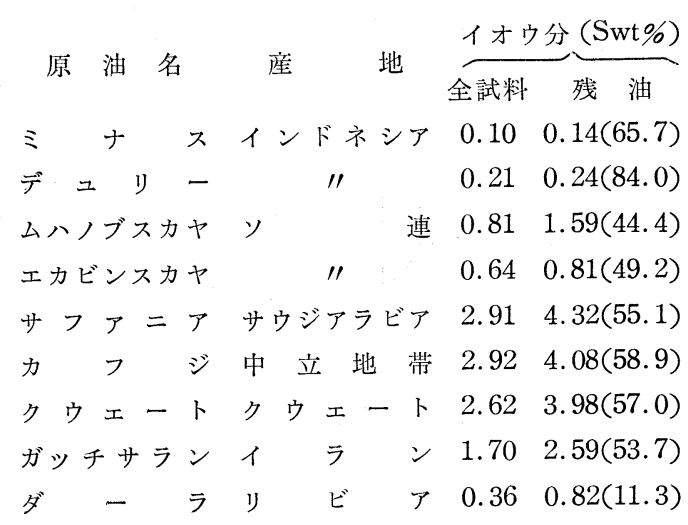

表 2 常圧残 油の金属含量

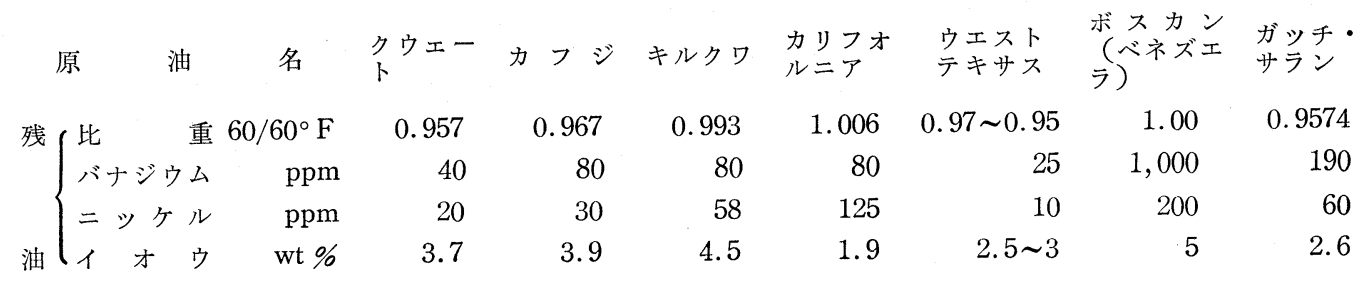


まれ，その大部分は残油に入るといわれている。表か らわかるように金属元素の量は原油によつてかなり差 が女り，とくに多いバナジウムとニッケルについての 比も原油によつて異なつている。

さらに残油中のアスファルテンの量や性質も原油に よつて異なることが知られているが，この点は現在も 研究されているのでここに注触れない。

\section{3: 残油の水素化脱硫}

石油中のイオウ化合物を除去する方法には溶剤抽出 法や吸着分離法なじがあるが，これら残油にたいし て実用されたことはなく, 生化学的な方法も現在研究 されているが，まだ実用化に程遠いと思われる。結局 現在残された実用的な脱硫方法は水素化脱硫のみとい つてよい。事実この方法は留出物の脱硫に広く用いら れており，その方法なども詳しく知られている。

石油類を水素化脱硫すると, イオウ化合物が水素化 分解されて炭化水素と硫化水素を生ずる反応と併行し て, 不飽和結合を持つ炭化水素の飽和および炭素間の 結合の水素化分解, すなわちハイドロクラツキングの 反応が起こる。脱硫反応が単独に起こるとすると, 残 油 $1 \mathrm{k} l$ 中のイオウ $1 \%$ を除くに必要な水素は約 14 $\mathrm{m}^{3}$ (N.T.P.) であるが, 水素付加や八イドロクラツ キングが起こるために，ふつらの石油を脱硫すると
$25 \sim 250 \mathrm{~m}^{3}$ の水素が消費される。八イドロクラッキ ングによつて生ずる低級炭化水素はガソリン，ナフ少 などに用いられるので，これらの需要が大きい時は八 イドロクラッキングを起こさせる方が有利であり，事 実アメリカではこのような脱硫方法が試みられてい る。他方わが国の現状では水素の価格が高く，低級炭 化水素の需要が重油に比較して少ないので，八イドロ クラッキングを避ける方法がその研究の目的となつて いる。

水素化脱硫のプロセスはいくつか提案されている が，工業的に操業しているのは現在では 2 種であり， その一つは昭和 43 年 9 月操業を開始した出光興産千葉 製油所の RCD Isomax 法で, 世界最初の大型プラン トで, 処理量は $40,000 \mathrm{bbl} /$ 日 といわれている。この 操業についてはかなり詳細に発表されている22ので, 適宜御参照載きたい。他の一つは $\mathrm{H}-\mathrm{O}$ il 法といわれ ているプロセスであり，これについては以下に記そ う。いずれもハイドロクラッキングによる軽質化を目 的とした方法であるが，条件によつてはわが国の現状 に適した操業が可能であるといわれている。これらの 方法を比較検討する際の資料として RCD Isomax 法 の工程図を図 1 に, 結果の一例を表 3 に示しておく。

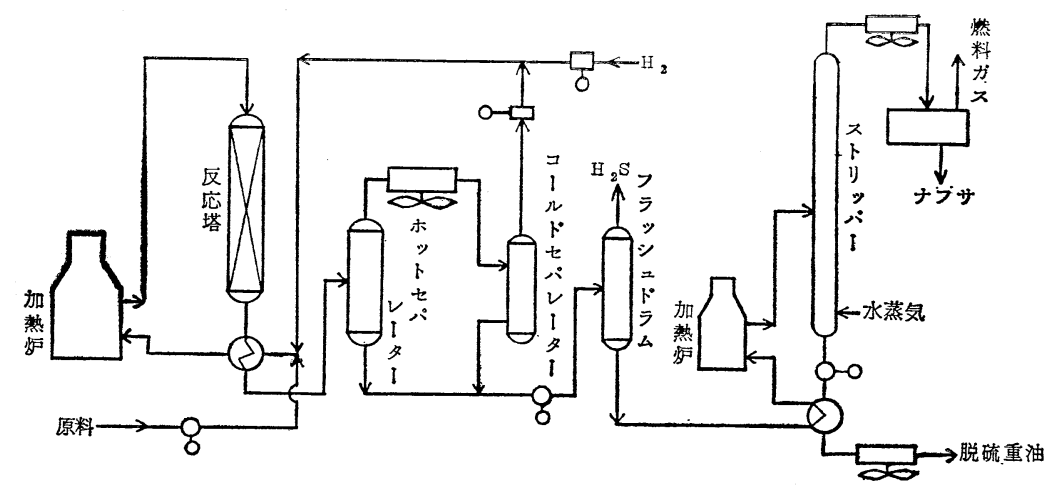

図 1

表 3 UOP RCD Isomax 法推定値

\begin{tabular}{lr|c}
\hline \multicolumn{1}{c|}{ 原料油性 } & 状 & 製 品 性 状 \\
\hline 比重 $60 / 60^{\circ} \mathrm{F}$ & 0.9554 & 0.9111 \\
沸点範 围 & $343^{\circ} \mathrm{C}<$ & $204^{\circ} \mathrm{C}<$ \\
イオウ含量 & $3.8 \mathrm{wt} \%$ & (収 量 $3.649 \mathrm{kl} /$ 日) \\
粘 度 $50^{\circ} \mathrm{C}$ & $245 \mathrm{cSt}$ & $60 \mathrm{cSt}$ \\
水素消費量 & $550,000 \mathrm{Nm}^{3} /$ 日 (損失量を含む)
\end{tabular}

\section{H-Oil 法3)}

H-Oil 法は Cities Service Oil 社および Hydrocarbon Research 社によつて共同開発され, 反応塔の 設計および塔内の触媒移動方式が特殊なので，従来の 方法では処理することが困難な原料油たとえば以下の ものにでも適用可能なプロセスであるといつてよい。 (1) 重質残油（ニッケルまたはバナジウム含有量の高 
いものを含めて）

(2) プロパン脱れきアスファルト

(3) 重質軽油（飛沫同伴された固体粒子を含有してい る FCC 装置よりの循環油およびコーカー軽油も含 めて)

(4) 天然アスファルト，タールサンドおよび重質原油 H-Oil 法は Cities Service 社の Lake Charles 製 油所で，過去 5 年間にわたり小規模運転 (2,500 bbl) 日)に成功している。昭和43年末には, Kuwait National Petroleum Company (KNPC) で, 28,000 bbl/日 の 2 番目のコマーシャル 装置が稼動する計画であうた が，これは種々の理由からまだ正常運転に入つていな いといわれている。米国においては, Humble Oil 社 が H-Oil 法のライセンスを得，現在大型装置を建設 中である。また Petroleos Mexicanos (PEMX) でも, Salamanca 製油所に $18,500 \mathrm{bbl} /$ 日 の装置を建設す ベく現在传計中である。

H-Oil プロセスが他の水素化プロセスと異なる著し い特長は，沸とう床 (ebullating bed) 触媒方式を使 用していることである。この方式では, 液相の炭化水 素油とガス相の水素との混合相が, 反応塔の下から上 へ流れて触媒層を拡大させ, しかも表面積の大きい微 細な触媒粒子を連続的に不規則運動させ, あたかも触 媒が沸とうしているごとき状態を呈する。この方法は 重質の污染油を処理する時に，とくにその優位性を発 揮する。それらの特長を列記するとつぎのとおりであ る。

（1）触媒は運転中に出し入れ可能である。したがつて 触媒の添加量を加減することにより，触媒活性を所 望の水準に一定に維持できる。金属含有量の多い原 料油を処理する時でも，触媒の再生，交換などのた めにシャットダウンすることなく，連続的に運転可 能である。

（2）触媒は反応塔内の内部循環液によつて沸とう状態 を維持され，それによつて反応塔の等温が達成され る。このことは反応温度調節に，高価なしかも手の こんだ急冷方式を必要としない。

（3）触媒は一定な運動状態にあるので，原料中に含ま れる微粒子は, 運転上何らの支障もなく反応系を通 過する。これは，処理中および貯蔵中に蓄積した固 形物を含んでいるような残油を処理する場合とか, コーカー軽油や FCC のディカント油のように,

H-Oil 法で処理する前にすでに固形物を含んでいる ような油を処理する場合，とくに重要である。この ような特長を有しているため, 固形物除去設備など
は, H-Oil 法原料油の前処理設備として不要であ る。

（4）今まで述べた特長は，本質的には機械的なもので あるが，これに加えて沸とら床は残油を処理する優 れた反応塔としてつぎの二つの特長を有している。 第一に, 沸とう床は圧力損失が小さい連続的な液相 状態にあるので, ガス相速度は相対的に液相のそれ にくらべて下向流の固定床の場合よりより速い。そ の結果, 水素化分解を伴つた運転においては, 留出 油は生成すると同時に反応塔系外に出るが，重質物 質は反応塔内に蓄積する傾向があり，したがつてこ れらの物質の残留時間は長くなる。第 2 としては, H-Oil 法反応塔系は圧力損失が小さいので, 固定床 方式より触媒サイズの小さいものを使用できる。こ れは明らかに通常使用されている $1 / 8$ in またはそ れ以上の触媒より効果的である。

プロセスの詳細については図 2 を御参照載きたい。 原料油は貯蔵温度の状態でポンプにより吸引され, 常 圧蒸留塔残油と熱交換し予熱される。この後さらに反 応塔圧力までポンプにて昇圧され，所定温度まで昇温 するため加熱炉に張込まれる。低温高圧分離槽よりの 水素に富んだ循環ガスと補充水素ガスは，それぞれ圧 縮機で反応塔圧力まで圧縮され，混合した後反応塔一 の循環水素ガスとして使用される。循環水素ガスは高 温高圧分離槽よりの気体と熱交換し予熱され, 所定温 度まで昇温するためさらに加熱炉に張込まれる。原料 油と循環水素ガスは加熱炉出口で混合し, 主要反応が 起こる一次反応塔の下へ張込まれ上に向つて流れる。 一次反応塔からの全流出物は，さらに残りの反応およ び品質向上を行なわせるために二次反応塔に張込まれ る。各反応塔で原料油は脱硫および一部水素化分解さ れる。原料油と循環水素ガスは反応塔の下へ張込まれ るが，この中液体が静置状態の触媒を拡大させ沸とう 状態にする。これには原料油のみのエネルギーでは不 足で, 内部液循環によつて補つてやる必要がある。液 体を循環するための循環ポンプは, 反応塔内または反 応塔外に設置する二方法がある。またポンプの駆動方 法も油圧方式および電動方式の二方法がある。

反応の経過とともに触媒の活性は劣化してくるが， これは加熱炉出口 と反応塔の 温度差によつて判定す る。触媒の反応塔への添加および抜き出しは, 運転を 中止することなく半連続的に簡単に実施できる。触媒 はアルミナ相体のコバルトーモリブデン系であり, 原 料油の組成によつて変わつてくるが一般的に $0.1 〜$ $0.2 \mathrm{lb} /$ 原料 bbl の消費量である。触媒の添加, 抜き 


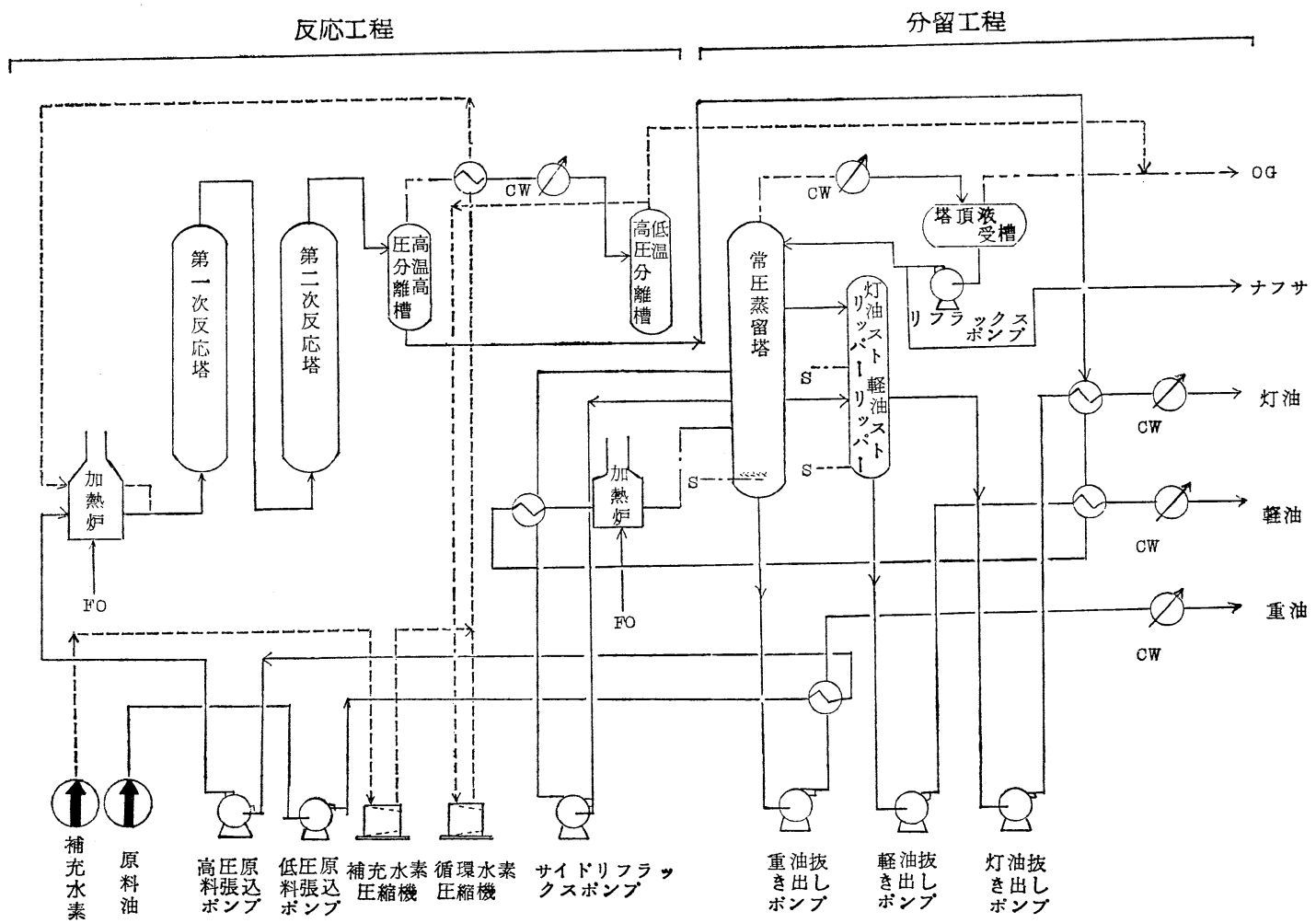

図 2

出しに伴い, 沸とう状態にある触媒レベルの確認が必 要となるが，これには $\gamma$ 線を利用する。

二次反応塔からの全流出物は, 高温高圧分離槽に導 かれ気液に分離される。分離された気体は循環水素ガ スと熱交換した後, 冷却器で泠却され低温高圧分離槽 に送られ，さらに気液分離される。ここで分離された 気体は水素濃度が高いので, 補充水素とともに圧縮さ れ熱交換後 H-Oil 反応塔に循環される。高温高圧分 離槽で分離された脱硫液は, 低温高圧分離槽で分離さ れた液体とともに, 常圧蒸留塔の側流およびサイドリ フラックスと熱交換し, 分留工程に張込まれる。熱交 換器で予熱された脱硫液（分離槽で分離された液体） は加熱炉で所定温度まで昇温され, 常圧蒸留塔に張込 まれる。塔頂からはナフサ留分, 側流として灯油およ び軽油留分を抜き出し, 塔底からは残留として主製品 である。脱硫重油を抜き出す。ナフサは塔頂コンデン サーで冷却され，一部は塔頂温度調節のためリフラッ クスとして使用し，他は製品として抜き出す。灯軽油 はストリッパーで引火点および蒸留性状を改善し, 供 給脱硫液と熱交換した後クーラーで泠却し 製品とす る。残油は H-Oil 法原料油と熱交換した後クーラー

\section{表 4 クェート常圧残油の品質}

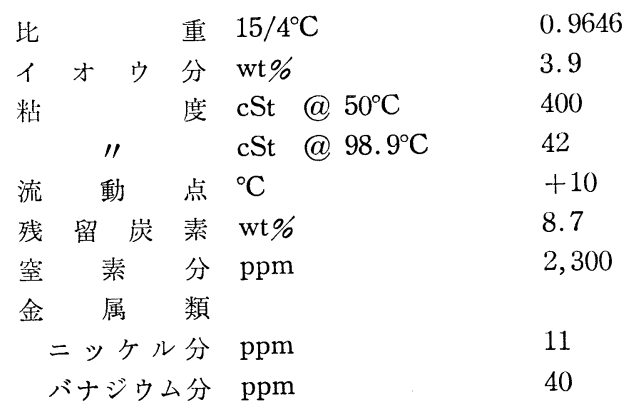

表 5 クェート常圧残油を脱硫した場合の製品品 質の一例

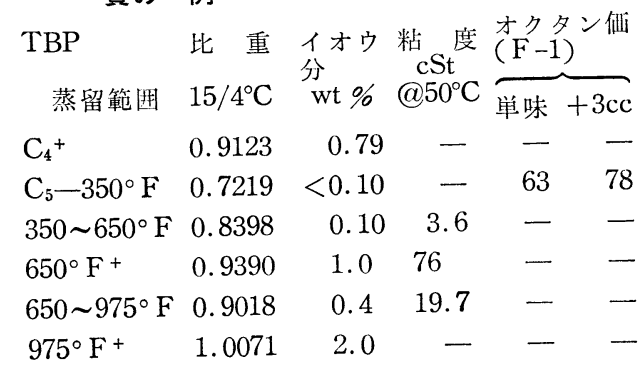


で冷却し製品とする。

製品の品質および収率は原料油の種類や運転の条件 によつて変化する。一般的なクエート常圧残油を脱硫 する場合の原料油の品質を表 4 に，えられた製品の 品質の一例を表 5 に示した。さらに表 6 に収率を示 した。

この場合の触媒使用量は $0.12 \mathrm{lb} / \mathrm{bbl}$ で, 水素消費 量は原料 $\mathrm{k} l$ 当たり $670 \mathrm{SCF} / \mathrm{bbl}$ である。

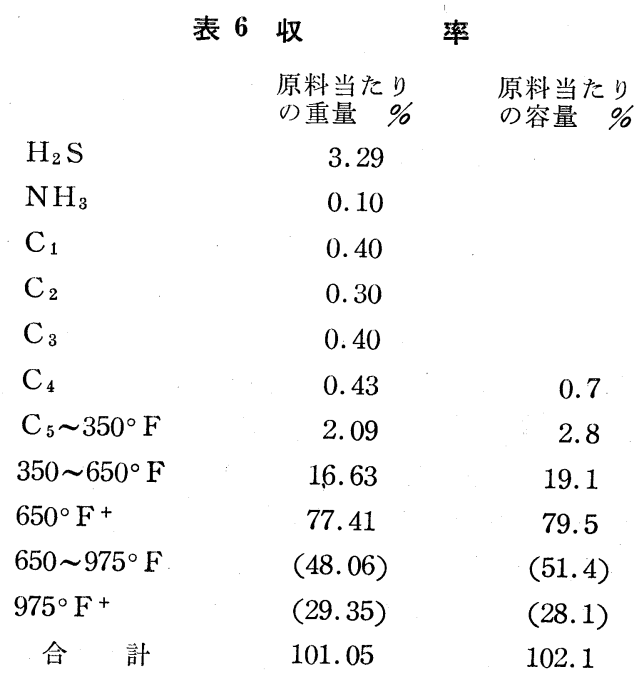

\section{5. 東京工業試験所における重油脱硫研究の} 現状

5-1 プロセス部門での考え方

東工試においてはまず H-Oil 法について検討し， ついで新しいプロセスの開発を目的として研究を行な つてきた。固定床方式では反応熱の制御および触媒寿 命の問題があるが，H-Oil 法ではこの二つの点では問 題が少ないといわれている。しかし後者は完全混合に 近いために反応という点をみると反応物の平均帯留時 間は一定でも個々の反応物の滞留時間には著しく長短 があり, 軽質化を起こしやすいことや一定空間速度に 対してピストン流と比べて反応率が低くなることなど が問題である。これらの点について図 $3 \sim 5$ について てデータで説明しよう。

四 3 はガス流速 $U_{g}$, 液流速 $U_{L}$ と触媒層の膨張比 $L_{f} / L_{m f}$ の関係を示している。 $L_{f} / L_{m f}$ は触媒を充填 し，一度流動させて止めた時の触媒層の高さと流動中 の層高との比で，この值が 1 以上は触媒層の膨張を表 わし，1以下はその逆を表わす。図からわかるように 液速 $U_{L}=0.90 \mathrm{~cm} / \mathrm{sec}$ が触媒層が膨張（すなわち

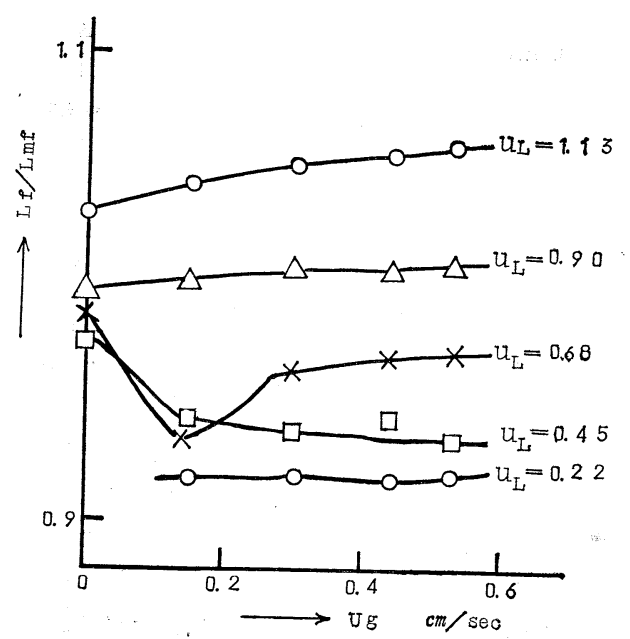

図 3

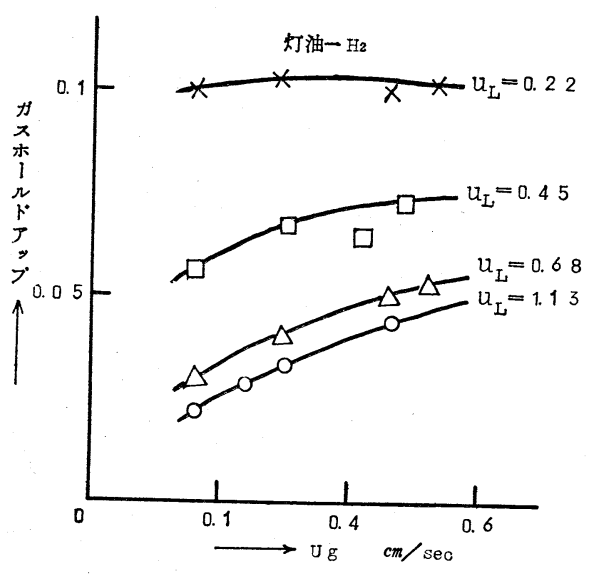

図 4

流動化）する限界で，これ以下の液速ではガスを通す ことによつて触媒層が最密充填の方向に近づき固定床 に近くなる。図 4 は, ガス流速 $U_{g}$, 液流速 $U_{L}$ とガス のホールドアップ(触媒粒子間に存在する気相の部分) の関係を示したもので, 液速が遅いとガスホールドア ップが増加することがわかる。図 5 は, 反応器を出 た生成油を一部リサイクルしてやる場合の循環比の影 響を示しており，循環比を下げると反応率が上がるこ とがわかる。生成油のリサイクルは一般的には，触媒 層を沸騰 (流動) させ，したがつて反応熱の制御を容 易にするといら目的をもつている。触媒粒子径が大き いとリサイクルが必要であるから, リサイクルをでき るだけ小さくするために触媒粒子を微細にし, いわゆ 


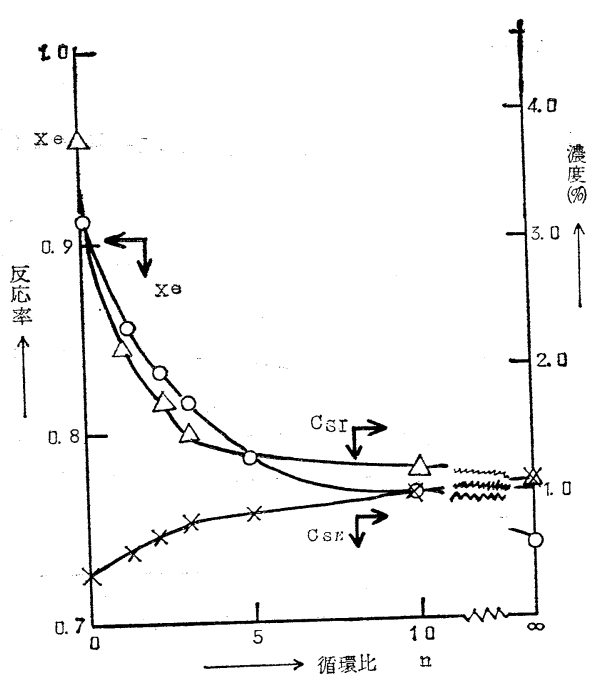

図 5

る，Kölbel 法に近づけようと改良が加えられている ともいわれている。図5 には入口に扮ける重油のイオ ウ濃度 $C_{S I}$ と出口のそれ $C_{S E}$ が循環比 $n$ に対して プロットされている。 $n=\infty$, すなわち完全混合の場 合は, $C_{S I}=C_{S E}$ になり, 図 5 から循環比 $n$ を下げ た方が，反応に有利であることがわかる。一方りサイ クルを少なくすることは触媒の流動に不利になること がわかつている。われわれはこの二つの矛盾をつぎの ように考えて解決しょうと試みた。すなわち必ずしも 触媒を浮遊させなくとも，一定位置に固定された触媒 層の下から，運転を停止することなく触媒を抜き出せ れば，H-Oil の利点と固定床の利点をともに生かせう る可能性があると考えてよい。この場合, 固定床の研 究で，触媒を流動させなくても触媒粒子が凝集しない ことがわかつていたので, 触媒の抜き出しは可能性が あり, また, 最密充填に近い所まで触媒を固定してお いて，下から原料を流し込んでやる Up-flow 方式を とれば循環比を小さくできると考えられる。以上の観 点で開発をす寸めたのが東工試のプロセスである。つ ぎに現在まで行なつた研究の結果を記そう。

\section{5-2 試験運転の装置および結果}

東京工業試験所第 6 部においては重油直接脱硫のプ ロジェクトを開始した時点において, 流動床型の触媒 反応についての化学工学的な研究を実施しており, 当 時の反応管はその径が $30 \mathrm{~mm}$ のものであつた。そこ で最初に $100 \mathrm{~mm} \phi$ の反応管を用いて本研究に当たつ たのである。

この場合には結果も公表したので，以下にその詳細
なデータを記した。引続いて $200 \mathrm{~mm} \phi$ の反応管によ る研究を行ない, 結果として 400 時間の連続運転や 触媒の抜き出しが可能であり, 脱硫率としても 100 $\mathrm{mm} \phi$ の結果とほぼ同程度の值をえているが，詳細な 結果をまとめている段階であるために，以下にはその フローシートと操作方法等を記すに止めておく。

$100 \mathrm{~mm} \phi$ の反応装置による脱硫の研究では, 内径 $100 \mathrm{~mm}$, 高さ $2,000 \mathrm{~mm}$ の反応管を主体とする, 試験 装置により, 反応温度 $360 \sim 400^{\circ} \mathrm{C}$, 反応圧力 $100 \sim$ $200 \mathrm{~kg} / \mathrm{cm}^{2}$ 原料重油 WHSV 0.5 2.0 の範囲で実験 を行なつた。当初は触媒粒子を完全に流動化した状態 で反応を行ならことについて検討していたが，その後 とくに触媒粒子を流動化しなくても, 反応は容易に行 なわれ, 触媒粒子の反応中における供給, 排出が可能 であることを確かめたので, 静止触媒床中を反応液を 上昇させる反応方法, すなわち, 移動床反応方式一と 発展させた。前者は温度の均一性にすぐれているが, 触媒充て儿密度が低く, 反応液循環量が大であるのに 比へ，後者は触媒充て儿密度が高く，反応液循環量は 少なく, ピストン流に近く, また灌液型固定床と同程 度の温度分布を示す。

表 7 に原料油性状, 表 8 に静止床による反応実験の 1 例を示す。な扔本件に用いた触媒はアルミナに $3 \%$ のコバルトおよび $11 \%$ のモリブデンを加えたもの で，第 6 部内において試作したが，その詳細について は最近のらちに発表される予定である。

つぎに $200 \mathrm{~mm} \psi$ の反応装置について記そう（図 6)。原料重油は原料水素および循環水素と混合したの ち, 予熱され, 循環油とともに反応管下部に供給され る。反応管に充てんされた静止触媒床中を重油および 水素は上昇しながら反応する。高温分離器においてガ スと液とは分離され，脱硫重油は原料と熱交換した 後, 減圧計量される。脱硫油の一部は高温循環ポンプ により，反応管に循環される。反応ガスは循環ガスと 熱交換した後, 低温分離器で分解油を分離し, 洗浄塔

\section{表 7 原料重油性状}

\begin{tabular}{cccc}
\multicolumn{1}{c}{ 原 } & \multicolumn{1}{c}{ 料 } & カフジ常圧残油 \\
比 & 重 & $15 / 4^{\circ} \mathrm{C}$ & 0.975 \\
粘 & 度 & $\mathrm{cSt} @ 50^{\circ} \mathrm{C}$ & 402.6 \\
イオウ分 & ${ }^{\mathrm{w} t} \%$ & 4.26 \\
初 & 留点 & ${ }^{\circ} \mathrm{C}$ & 267 \\
$5 \%$ & ${ }^{\circ} \mathrm{C}$ & 288 \\
$10 \%$ & ${ }^{\circ} \mathrm{C}$ & 300 \\
$300^{\circ} \mathrm{C}+$ & $\%$ & 90
\end{tabular}




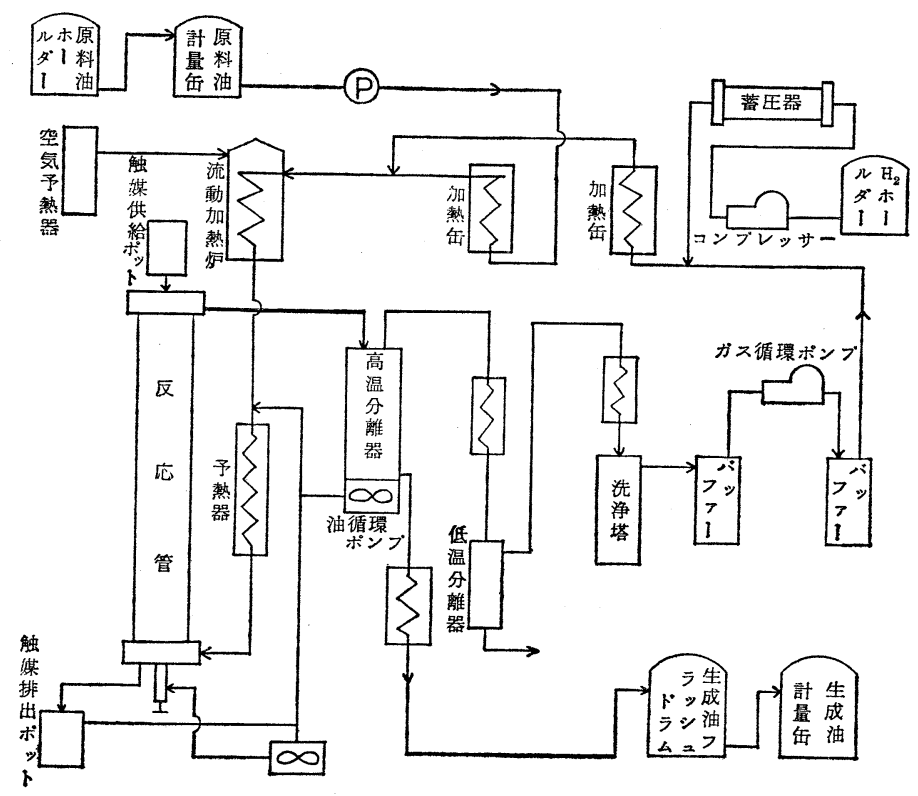

図 6

表 $8100 \phi$ 重油水素化脱硫試験装置による実験 結果

\begin{tabular}{|c|c|c|c|}
\hline 実 験 番 号 & A & B & $\mathrm{C}$ \\
\hline 反応 温 度 & 387 & 389 & 368 \\
\hline 反応压力 $\left(\mathrm{kg} / \mathrm{cm}^{2}\right)$ & 200 & 200 & 200 \\
\hline WHSV & 1.03 & 1.63 & 1.62 \\
\hline 脱硫油収率（wt\%） & 87.7 & 89.7 & 96.7 \\
\hline 分解油收率 (wt\%) & 8.7 & 4.8 & 2.4 \\
\hline 脱 硫 率 & 81.6 & 76.1 & 57.1 \\
\hline 水素消費量 $(l / \mathrm{kg})$ & 112.8 & 117.4 & 89.2 \\
\hline 㸚品 性 状 & & & \\
\hline 粘度 (cSt @100C) & 24.8 & 25.5 & 40.2 \\
\hline 重 $15 / 4^{\circ} \mathrm{C}$ & 0.923 & 0.932 & 0.946 \\
\hline イオウ分 (wt\%) & 0.90 & 1.17 & 1.93 \\
\hline 初 留 点 & 167 & 154 & 198 \\
\hline
\end{tabular}

にて硫化水素, アンモニアを洗浄除去し, 大部分は循 環使用され, 系内の水素分圧を一定に保つよう, 一部 は系外に抜き出される。触媒は球状粒子を使用し, 反 応中に反応管上部より新触媒あるいは再生触媒を連続 的あるいは間けつ的に供給し, 反応管下部より活性低 下した触媒を抜き出すことによつて, 反応管中で触媒 の活性レベルを一定に保つことができるようになつて いる。

\section{6. 重油脱硫用触媒}

この問題は本稿の目的と離れたものを含んでおり, 比較的発表も少ないので，簡単に記したいが，筆者の 研究室などで行なつた研究などを中心として記してみ よう。ただし内容がやや基礎的なものにかたよること をあらかじめ御了承いただきたい。

現在まで発表された触媒としては，そのほとんどが アルミナにコバルトおよびモリブデンを担持したもの を用いている。コバルトをニッケルで，モリブデンを タングステンで置換したものについて報告されたこと があり, さらにアルミナに他の添加物を加えた効果に 関する研究も散見される。アルミナの製造条件とその 担体または触媒としての活性や，そのままあるいは担 持後の成形性などについては筆者の研究室をはじめと してかなり多くの研究がみられるようになつている が，その詳細は別に御参照賜わりたい425)。

担体としてのアルミナに要求される因子はその比表 面積, 細孔の大きさと分布, これらと関連の深い一次 粒子および二次粒子のモルフォロジーなどがある。比 表面積は一般的には大きい方が望ましいが，さらに細 孔の大きさも問題である。ここに $\bar{d}=4 V / S(V$ は単 位重量当たりの全細孔の容積, $S$ は比表面積とする。) とすると あ は平均細孔直径であるが，これは一次粒 子の間隙の平均の大きさを示している。 $\bar{d}$ が小さい と反応の進行が細孔内の生成物または反応物の拡散に 
よつて妨げられるのでこの場合には $S$ が大きい方が よいとも結論できない。しかしこの場合に同時に $V$ が大きいならばよいことになり, ゲル状の沈殿からつ くつたアルミナではこの条件を満足するので, $S$ も $V$ も大きくなるといわれている。アルミン酸ソーダと硫 酸アルミニウムとの反応によつて生じた沈殿は温度や $\mathrm{pH}$ などによつて繊維状のベーマイトゲル $(\mathrm{AlO} \cdot \mathrm{OH})$ または $\mathrm{Al}_{2} \mathrm{O}_{3} \cdot \mathrm{H}_{2} \mathrm{O}$ を生ずる場合や六角板状のバイヤ ライト $\left(\mathrm{Al}(\mathrm{OH})_{3}\right.$ または $\left.\mathrm{Al}_{2} \mathrm{O}_{3} \cdot 3 \mathrm{H}_{2} \mathrm{O}\right)$ を生ずる場 合があり，これを熱分解して得られるアルミナの細孔 構造に著しい差異をもたらすことが知られている。す なわち, ベーマイトゲルから得られたアルミナでは, 加熱脱水により一次粒子およびそれらが無定形に集つ てできる二次粒子の大きさの変化が少なく，その細孔 は一次粒子の寸き間にできる半径 $20 \sim 50 \AA$ のものの 他に，一次粒子凝集状態のちがいにより比較的広い範 囲に分布する細孔（50 150 ^̊) が多い。これに対し， 結晶性バイヤライトから得られるアルミナは, 水和物 の加熱脱水により結晶に割れ目が入り大きさのそろつ た微細粒子（一次粒子）に分れるため, 細孔はその間 隙に生じた半径 20 30 凡 に鋭いピークを持つ分布を 示す。それゆえ反応中の細孔内拡散が問題になる場合 には，結晶性水和物から生成されるアルミナの活性は 劣る。

アルミナにコバルトおよびモリブデンを担持する工 程についてはわずかに特許などで知られるのみであ り，その研究は非常に少ない。アルミナに両者の塩の 水溶液を混合してねりあわせた場合と成形したアルミ ナを上記の溶液に浸漬した場合との活性の差が発表さ れているが6)，この場合に脱硫活性についての発表は 全くみられない。同じことは市販されているこの系の 触媒についてもいえることであり，その活性点の検 討は行なわれているが，脱硫に用いた場合にはその 上に沈積したバナジウムの状態が検討されたに過ぎな い7)。この系の触媒は軽油や灯油の脱硫に用いられて いるために，一部市販されており，これらについての $\mathrm{X}$ 線，赤外，磁気的方法などを用いた結果が最近発 表されている8)。これらではコバルトおよびモリブデ ンの状態が問題となつており, モリブデン酸コバルト やアルミン酸コバルトの生成についても結果が一致せ ず，さらに以上の結果からの活性点の推定についても 種々の仮説が提出されている。脱硫後のバナジンの沈 積についても近く発表される結果からみるととくに活
性に直接影響することは予想しにくい。他方この系の 触媒の機械的強度はアルミナだけの場合のそれより大 きいことは確められて抢り 9)，この点だけでも興味媣 、研究対象の一つであろう。結論的にはこの系の触媒 の脱硫活性についてはいまだに問題が多く残されてお り，今後の研究にまつところが大きい。

\section{7.あとがき}

本稿を記している間に固定床方式による Gulf HDS 法が日本鉱業水島製油所に扔いて順調に稼動している ことが報ぜられたし，流動床方式についても稼動する 時期が近いものも少なくない。これらに比べると東工 試の方式については現在の時点では優劣の判定を下す ことは筆者の立場からかなり当感を感ずる。しかしな がら重油により，あるいはその設置場所の地理的条件 などを考えると，東工試の方式の利点を生かしうる場 合があることは予想されるのである。このような考え 方についての御検討を心から期待して筆をおく。

本稿の記載に当たつて東工大名誉教授斯波忠夫氏の 御教導を受けたことを感謝する。また H-Oil 法につ いては肥料工業懇話会における東洋エンジニアリング 社井村氏の御講演から引用させて載いたことを記して おく。な打東京工業試験所第 6 部の加藤課長, 藤堂課 長および山田谷技官の御援助をうけたことおよび工業 技術院の緒方研究開発官の御許可をうけたことを感謝 する。

\section{文献}

1）斯波忠夫，化学々工業，21，192（1968）

2) M. Yamato, C.H. Watkins, Hydrocarbon Processing, 47, No. 5, 131 (1968)

3) 井村良造, 肥㤰講演要旨, 第 311 回 (1969)

4) 内田泚, 化学工学, 31，851 (1967)

5）小寺嘉秀, 藤堂尚之, 第 6 回粉体セミナーテキス 卜, p. 108 (1969)

6) 山田谷正子, 大場昌明, 小川清, 長谷川藤二, 荒 木道郎，小寺嘉秀，日化第21年会，大阪（1968）

7) 佐藤三男, 管孝男, 江本弘三, 松本敬信, 清水吉 一, 日化第21年会, 大阪 (1968), 加部利明, 藤堂 尚之，小寺嘉秀，日化第23年会，東京 (1970)

8) J.H.Ashley, P.C.H. Mitchell, J. Chem. Soc., A, 1968, 2821, J.M.J.G.Lipsch, G.C.A. Schuit, A. Catalysis, 15, 163, 174, 179 (1969)

9) S.Yamadaya, M.Oba, T.Hasegawa, K.Ogawa, Y.Kotera, J. Catalysis (in press) 


\title{
Hydrodesulfurization of Fuel Oil
}

\author{
by Yoshihide Kotera \\ (Government Chemical Industrial Research Institute, Tokyo)
}

\begin{abstract}
SYNOPSIS:-The hydrodesulfurization of fuel oil was reviewed. The minor component in fuel oil was tabulated. The engineering problems on the hydrodesulfurization was discussed, especially, work performed in a fluidized bed, socalled "H-Oil Process" was explained in detail. Studies on the hydrodesulfurization, which has been carried out in Government Chemical Industrial Research Institute, Tokyo, were described from two viewpoints, that are engineering problem and one of catalysts. The developement of a process, which belongs to a type of "Moving Bed" and is expected to be usefull in a commercial plant, was described with some data obtained. Catalyst employed in this process was $\mathrm{Co}-\mathrm{Mo}-\mathrm{Al}_{2} \mathrm{O}_{3}$ and the ralation between the methods of preparation and its characteristics were discussed.
\end{abstract}

